\title{
Immunohistochemical Localization of Glucocorticoid Receptors in Anterior Pituitary Cells of Rats
}

\author{
Ryoji Yokote, Setsuji Hisano and Shigeo DaIKokU \\ Department of Anatomy, Tokushima University School of Medicine, Tokushima, Japan
}

Received August 10, 1990

\begin{abstract}
Summary. Adenohypophysial cells having a glucocorticoid receptor were immunohistochemically determined in rats. For detecting the presence of the glucocorticoid receptor, we used the monoclonal antibody for a glucocorticoid receptor (BuGR-2), and immunohistochemically examined the phenotypes of the cells that exhibited BuGR-2-immunoreactivity. The immunoreaction for the glucocorticoid receptor was confined to the nuclei of the majority of corticotrophs $(70 \%)$ and of some somatotrophs in intact animals. Following adrenalectomy, all corticotrophs became significantly hypertrophic, losing their immunoreactivity for the glucocorticoid receptor. In contrast, somatotrophs that had also lost the immunoreactivity for the glucocorticoid receptor in the nuclei greatly diminished in size. Intraperitoneal administration of corticosterone was performed in adrenalectomized animals to supplement glucocorticoids. This treatment restored BuGR-2-immunoreactivity in the nuclei of some corticotrophs. In intact rats, immunolabeled corticotrophs were classified into two types, stellate and polyhedral. However, the immunoreaction for the glucocorticoid receptor was equally evident in the cell nuclei of these different types of cells. It is concluded that, in rats, both corticotrophs and somatotrophs are target cells of glucocorticoids, although these cell types display opposite growth responses to the removal of glucocorticoids.
\end{abstract}

Ever since the specific antibodies for the glucocorticoid receptor proteins became available in immunohistochemistry, the intracellular localization of the receptor has been able to be determined in neurons, in anterior pituitary cells, lymphatic tissues and liver cells at the light (PAPAMICHAIL et al., 1980; ANTAKLY and EISEN, 1984; ANTAKLY et al., 1985; CINTRA et al., 1987; PICARD and YAMAMOTO, 1987) and electron microscopic (LIPOSITS et al., 1987) levels. In the hypothalamichypophysial-adrenal axis, glucocorticoids play the role of a mediator. Immunoreactivity for the glucocorticoid receptor has been detected not only in the neurons containing corticotrophic hormone-releasing hormone (CRF) in the hypothalamus (LIPOSITS et al., 1987), but also in various other neurons (FUXE et al., 1985; GUSTAFSSON et al., 1987; HISANO et al., 1988). In the anterior pituitary using a polyclonal antibody for the receptor protein, ANTAKLY et al. (1985) have shown that the immunoreactivity was present in almost all of the anterior pituitary cells. It has been presumed that the glucocorticoid receptor might be expressed in ACTH cells, but this has not yet been evidenced. In the present study, we have studied the phenotypes of cells containing glucocorticoid receptors in the rat anterior pituitary by employing a double immunohistochemical staining method for the glucocorticoid receptor and each of the anterior pituitary hormones.

\section{MATERIALS AND METHODS}

\section{Animals and experiments}

Adult male Sprague-Dawley rats $(240-300 \mathrm{~g})$ were divided into six groups: normal, adrenalectomized, adrenalectomized and corticosterone-primed, shamadrenalectomized, corticosterone injected, and sesame-oil-injected control animals. Adrenalectomy was carried out bilaterally by a dorsal approach under ether anesthesia. The adrenalectomized rats were maintained on $0.9 \%$ saline ad libitum and killed 3 or 14 days after operation. Some of adrenalectomized rats were further treated with an intraperitoneal injection of corticosterone $(10 \mathrm{mg} / 0.1 \mathrm{ml}$ of ethanol and $0.9 \mathrm{ml}$ of saline mixture $/ \mathrm{kg}$ body weight) $4 \mathrm{~h}$ before sacrifice. Sham-operated rats were killed after 3 days. For 7 consecutive days, a large amount of corticosterone $(50 \mathrm{mg} / 5 \mathrm{ml}$ of sesame oil $/ \mathrm{kg}$ body weight/day) was injected subcutaneously into 3 intact 
animals. This dose of corticosterone has been previously shown to elevate blood steroid levels to those seen in response to major stressors (SAPOLSKY et al., 1985; O'CALLAGHAN et al., 1989). As the controls, the same number of animals were treated with sesame oil. The animals thus treated were sacrificed $4 \mathrm{~h}$ after the last injection.

All the animals were killed by decapitation in the afternoon $(13: 00-15: 00 \mathrm{~h})$. The pituitaries were rapidly removed and immersed in a modified Zamboni's fixative (4\% paraformaldehyde, $0.15 \%$ glutaraldehyde, and $0.2 \%$ picric acid in $0.1 \mathrm{M}$ sodium cacodylate buffer, $\mathrm{pH}$ 7.4) for $2 \mathrm{~h}$ at room temperature and then overnight at $4{ }^{\circ} \mathrm{C}$. The pituitaries were cut at a $50 \mu \mathrm{m}$ thickness on a vibratome. These sections were washed in $0.02 \mathrm{M}$ phosphate buffered saline (PBS), pH 7.4, and then processed for immunostaining with a monoclonal antibody against type II glucocorticoid receptor (BuGR-2) and with antisera to adenohypophysial hormones.

A polyclonal antiserum $\left(\mathrm{B}_{1}\right.$-antiserum; kindly supplied by Prof. N. Katunuma, Division of Enzyme Chemistry, Institute for Enzyme Research, The University of Tokushima, Japan) generated against a part of the rat glucocorticoid receptor molecule was also used to stain the pituitary. The preparation procedures used to produce the serum correspond to those used by ANTAKLY and EISEN (1984). The pituitaries were fixed in the abovementioned fixative or Bouin's solution without acetic acid, embedded in paraffin, and serially cut into sections $5 \mu \mathrm{m}$ in thickness. The sections were double stainded with $B_{1}$ antiserum and one of the antisera against pituitary hormones. These reactions were visualized by the avidin-biotin-peroxidase complex (ABC) method.

\section{Antisera}

The mouse monoclonal antibody BuGR-2 was kindly supplied by Dr. R. W. HARRISON, University of Arkansas for Medical Sciences. BuGR-2 was diluted to $1: 250$ with $10 \%$ normal horse serum (Cappel, USA) in $0.02 \mathrm{M} \mathrm{PBS}, \mathrm{pH} 7.4$, containing $0.1 \%$ sodium azide. The generation and characterization of BuGR-2 raised by purified rat liver glucocorticoid receptor have been previously published (GAMETCHU and HARRISON, 1984; EISEN et al., 1985). The staining specificity of the BuGR-2 was previously examined by the pre-absorption test (LiPOSITS et al., 1987; UHT et al., 1988).

For immunostaining the anterior pituitary hormones, we used the following antisera: anti-ACTH ( $1: 2000)$, -rat thyroid- stimulating hormone $\beta$-subunit $(\mathrm{rTSH} \beta) \quad(1: 10000)$, -rat growth hormone $(\mathrm{rGH})$
(1:5000), -rat prolactin (rPRL) $(1: 5000)$, and -human chorionic gonadotropin (hCG) $(1: 4000)$. These antisera were diluted with $0.1 \mathrm{M}$ phosphate buffer containing rat liver extract and bovine serum albumin $(0.1 \%)$ to reduce background staining. The specificities of antiACTH (DAIKOKU et al., 1983), -rTSH $\beta$ (DAIKOKU et al., 1981), -rPRL (HISANO et al., 1984), and -hCG (DAIKOKU et al., 1980) were confirmed by preabsorption tests with the respective antigens. Anti-rGH (HAC-RT25-01RBP85) was kindly supplied by Prof. K. WAKABAYASHI (Institute of Endocrinology, Gunma University, Japan). The specificity of anti-rGH serum was examined by a non-competitive binding test (WAKABAYASHI and TANAKA, 1988), and possible cross-reactions with PRL, gonadotropins, ACTH or TSH were excluded at a dilution of $1: 200$ of the serum. The staining specificity of the anti-rGH serum was further tested by using adjacent serial sections stained alternately with the anti-rGH and -rPRL sera.

$\mathrm{B}_{1}$-antiserum was generated against the amino acid sequence, 407-423 (kind gift of Pharmacia LKB, Osaka, Japan), of the rat glucocorticoid receptor sequence predicted from cDNA isolated by MIESFELD et al. (1986). Intact rabbits were immunized 5 times at a 3 -week interval with $0.5 \mathrm{mg}$ of the peptide linked to the keyhole limpet hemocyanin. The specificity of the $\mathrm{B}_{1}$-antiserum was tested by the Western blotting procedure. Intact and adrenalectomized rat liver tissues were separately homogenized with TEG buffer $(10 \mathrm{mM}$ Tes-KOH, pH 7.4, $1 \mathrm{mM}$ EDTA, 50 $\mathrm{mM} \mathrm{NaCl}, 10 \%$ glycerol, $20 \mathrm{mM} \mathrm{Na}$-molybdate) using Dounce homogenizer, and the supernatant of $100,000 \times \mathrm{g}$ centrifugation was referred to be cytosol. The cytosol ( $40 \mu \mathrm{g}$ of protein) was subjected to SDS polyacrylamide gel electrophoresis (SDS-PAGE) using 4/20 gradient gel (Daiichi Chemical, Japan) running at $4^{\circ} \mathrm{C}$. Immunoblotting was carried out by transferring protein from gel to Immobilon (Millipore). After blocking the blotting with $3 \%$ bovine serum albumin in TBS $(20 \mathrm{mM}$ Tris- $\mathrm{HCl}, \mathrm{pH} 7.5,0.15$ $\mathrm{M} \mathrm{NaCl}, 0.1 \%$ Tween-20), the sheet was incubated with anti-receptor serum diluted to $1: 100-500$ with $1 \%$ bovine serum albumin in TBS for $4 \mathrm{~h}$ at room temperature and immunostained with picoBrue ImmunoDetection kit (Stratagene) according to the procedures suggested by the manufacturer.

The $\mathrm{B}_{1}$-antiserum was further tested by an immunoadsorption test to determine the specific binding of the steroid. Liver cytosol prepared from the adrenalectomized rat was incubated with $50 \mathrm{nM}$ $\left[{ }^{3} \mathrm{H}\right]$-triamcinolone acetonide (TA) at $4{ }^{\circ} \mathrm{C}$ overnight with or without 1000 -fold excess of nonradioactive dexamethasone. Free steroid was removed with charcoal and the specific binding of glucocorticoids was 
$15000 \mathrm{cpm} / 150 \mu 1$ of cytosol. $150 \mu 1$ aliquots labeled with $\left[{ }^{3} \mathrm{H}\right]$-TA were incubated with either the preimmune serum or receptor antibody at $4^{\circ} \mathrm{C}$ overnight.
Each mixture was added to $40 \mu \mathrm{l}$ bed volume of protein A sepharose (Pharmacia) preequilibrated in TEG buffer which contained $0.2 \%$ Tween-20, and

$\mathbf{a}$
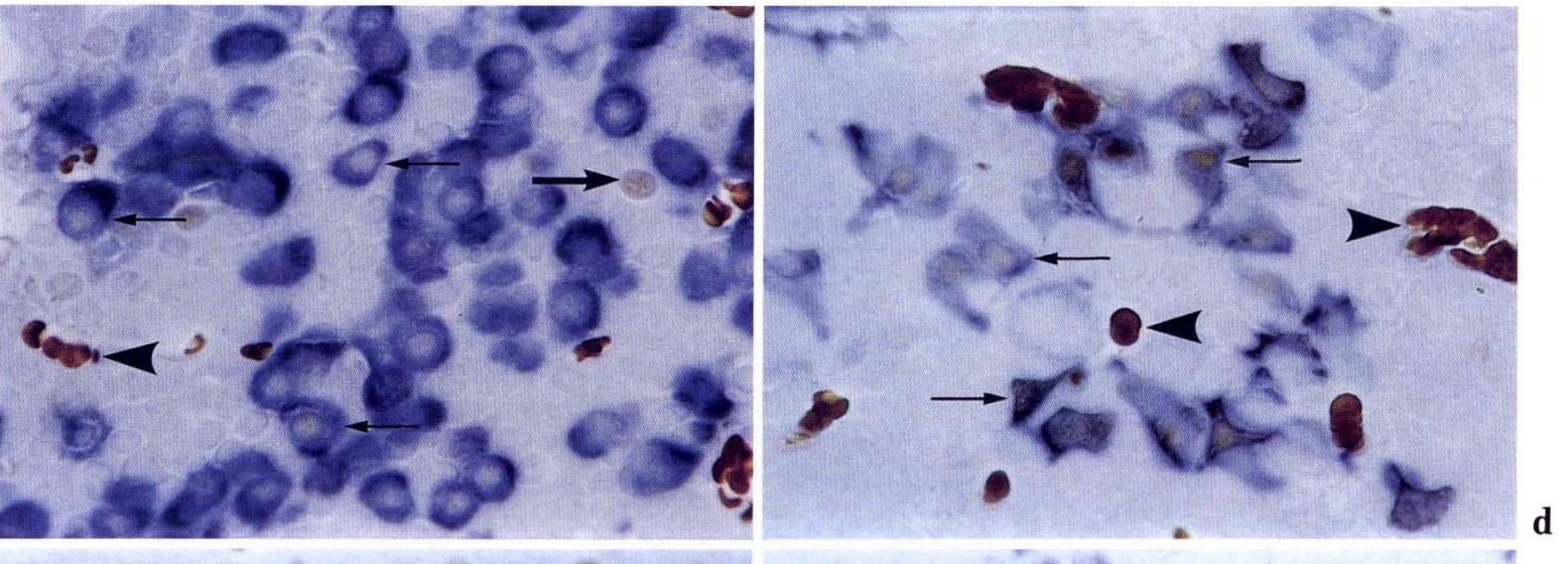

b
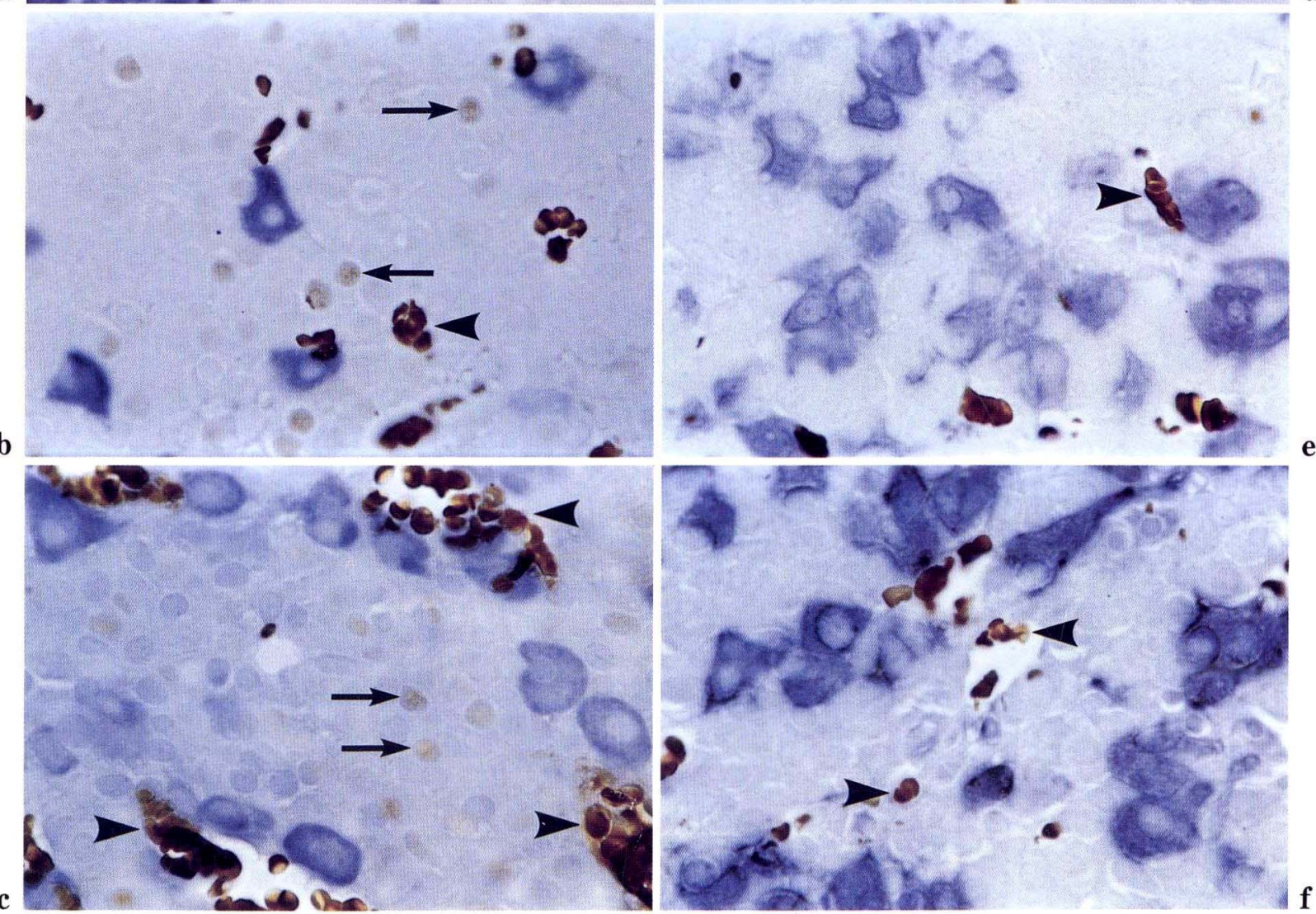

Fig. 1. Anterior pituitaries taken from an intact animal (a-d), and animals 3 days (e) and 14 days (f) after adrenalectomy. Cells immunoreactive for $\mathrm{rGH}(\mathbf{a}), \mathrm{rTSH} \beta(\mathbf{b}), \mathrm{hCG}(\mathbf{c})$ and ACTH (d-f) are colored blue with cobalt in the cytoplasm. The brown color immunoreaction for BuGR-2 is located in the nuclei of immunopositive cells (thin arrows in $\mathbf{a}$ and $\mathbf{d}$ ) and also in immunonegative cells (thick arrows in $\mathbf{a}-\mathbf{c}$ ). While only three somatotrophs are BuGR-2-positive (a), almost all ACTH cells in $\mathbf{d}$ are BuGR-2-positive. Note that adrenalectomy causes the disappearance of any immunoreaction for a glucocorticoid receptor (e and $\mathbf{f}$ ), and results in the hypertrophy of corticotrophs. In $\mathbf{f}$, immunoreactive stellate cells, which are predominant in intact animals, are no longer evident. Erythrocytes are shown with arrowheads. a-f: $\times 450$ 
then stirred at $4^{\circ} \mathrm{C}$ for $2 \mathrm{~h}$. Protein A sepharose was then pelleted by centrifugation and washed 4 times with $1 \mathrm{ml}$ of TEG buffer containing $0.2 \%$ Tween- 20 . The final pellets were counted for radioactivity. The $\mathrm{B}_{1}$-antiserum was diluted to $1: 200$ and used for immunostaining.

\section{Immunocytochemical procedures}

Vibratome sections of the anterior pituitary were treated according to the following schedule: 1) $0.2 \%$ Triton X-100 (Wako Pure Chemical Ind. LTD. Japan) in PBS at room temperature for $20 \mathrm{~min}$; 2) $10 \%$ normal horse serum in PBS containing $0.5 \%$ lysine, $0.5 \%$ glycine and $0.1 \%$ sodium azide for $1 \mathrm{~h}$ at $18^{\circ} \mathrm{C}$; 3) BuGR-2, or $10 \%$ normal horse serum only (as a negative control of BuGR) for $60 \mathrm{~h}$ at $4^{\circ} \mathrm{C}$; 4) biotinylated horse anti-mouse $\operatorname{IgG}(1: 200$, Vectastain $\mathrm{ABC}$ Kit, Vector Laboratories, USA) for $6 \mathrm{~h}$ at $18^{\circ} \mathrm{C}$; and 5) incubation in $\mathrm{ABC}$ (Vectastain $\mathrm{ABC}$ Kit) diluted with Tris-buffered saline (TBS), $\mathrm{pH}$ 9.6, for

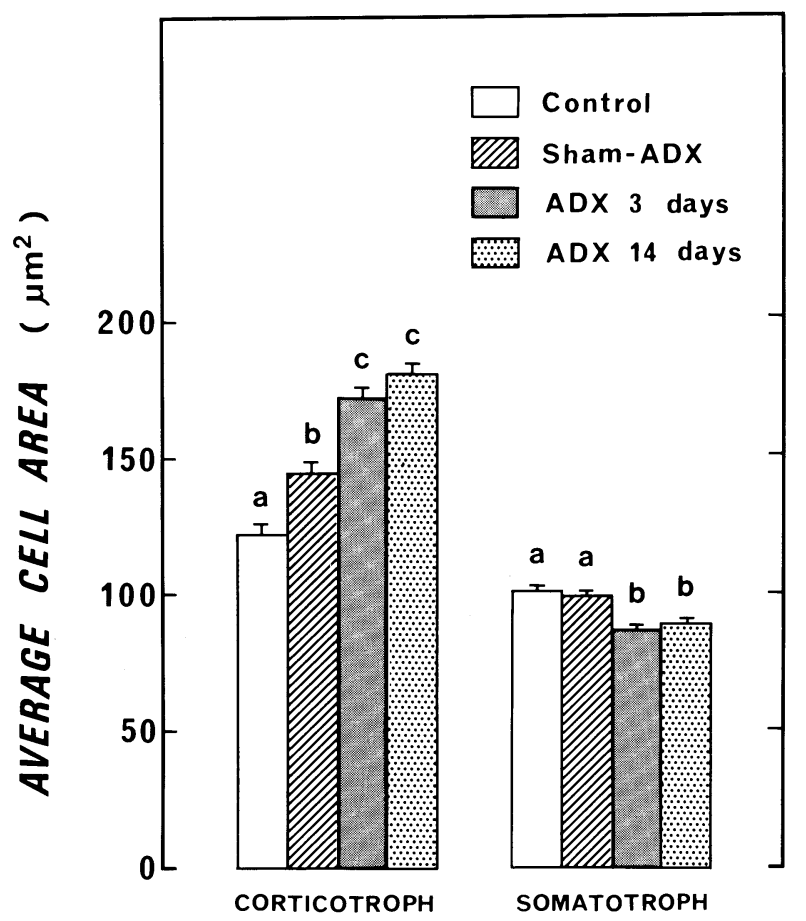

Fig. 2. Average cell areas of corticotrophs and somatotrophs of intact control rats, and of rats 3 days after sham-adrenalectomy (Sham-ADX), 3 days and 14 days after adrenalectomy (ADX). Significant differences $(P<0.05)$ are found between $\mathbf{a}$ and $\mathbf{b}$ in corticotrophs and in somatotrophs, and between $\mathbf{b}$ and $\mathbf{c}$ in corticotrophs. Corticotrophs increase in size after adrenalectomy, while somatotrophs decrease. Bars: standard errors.
$15 \mathrm{~h}$ at $4^{\circ} \mathrm{C}$. After incubation with each solution, the sections were washed with PBS or TBS. The immunoreaction for the glucocorticoid receptor was visualized with 3,3'-diaminobenzidine tetrahydrochloride (DAB) by incubating the sections in the following solutions: $5 \mathrm{mg} \mathrm{DAB}$ and $40 \mathrm{mg}$ glucose in $9.5 \mathrm{ml}$ of PBS, and $200 \mu \mathrm{l}$ of $0.03 \%$ glucose oxidase aqueous solution. The tissue sections were incubated in this solution for $20 \mathrm{~min}$ at $35^{\circ} \mathrm{C}$; thereby the immunoreaction for the glucocorticoid receptor was colored brown. The sections were rinsed several times in PBS.

Most of the stained vibratome sections were immersed in a warmed agar-gelatin mixture $(5 \% \mathrm{wt} / \mathrm{vol}$ of Bacto-Agar, Difco, and 2\% wt/vol of gelatin, Merk, in distilled water) for $1 \mathrm{~min}$ and flat embedded in the solidified mixture in a cold bath. The agargelatin blocks were cut into small pieces, dehydrated by an ascending ethanol series, embedded in paraffin in vacuo, and serially cut at a $5 \mu \mathrm{m}$ thickness. These sections were mounted separately on different albumin-coated glass slides. Each section was then immunostained respectively with one of the antisera against the aforementioned adenohypophysial hormones. Immunostaining was performed as follows: 1) $3 \%$ hydrogen peroxide for $15 \mathrm{~min}$ at room temperature to eliminate endogenous peroxidase activities; 2) incubation with each antiserum overnight at $4^{\circ} \mathrm{C}$; 3) biotinylated goat anti-rabbit IgG $(1: 200)$ (Vectastain $\mathrm{ABC}$ Kit) for $1 \mathrm{~h}$ at $32^{\circ} \mathrm{C}$; and 4) $\mathrm{ABC}$ reagents (Vectastain $\mathrm{ABC}$ Kit) for $1 \mathrm{~h}$ at $32^{\circ} \mathrm{C}$. After each staining step, the sections were washed in distilled water for $10 \mathrm{~min}$. DAB-Co ion solution was prepared by dissolving $20 \mathrm{mg}$ of $\mathrm{DAB}$ in $40 \mathrm{ml}$ of Tris- $\mathrm{HCl}$ buffer, $0.05 \mathrm{M}, \mathrm{pH} 7.6$, and then by adding $0.4 \mathrm{ml}$ of $1 \% \mathrm{CoCl}_{2}$. The sections were incubated in the DABCo ion solution for $5 \mathrm{~min}$, and for a further 2-3 min after adding $10 \mu \mathrm{l}$ of $3 \% \mathrm{H}_{2} \mathrm{O}_{2}$ in the solution (Hsu and SOBAN, 1982). Hence, the immunoreaction for each anterior pituitary hormone was blue, in sharp contrast with the brown immunoreaction for the glucocorticoid receptor.

The immunostaining with the $\mathrm{B}_{1}$-antiserum was performed in the same manner as that indicated in the immunostaining with anti-pituitary hormones. The staining specificity of the serum was examined by an absorption test of the serum after adding the antigen $(1$ or $10 \mu \mathrm{g} / \mathrm{ml})$ to the antiserum.

\section{Morphometric procedure}

To estimate the morphological alterations of corticotrophs and somatotrophs, we determined the average areas of these cells of the intact, adrenal- 
ectomized ( 3 and 14 days postsurgery) and shamadrenalectomized (3 days postsurgery) animals by using a computerized superimposing system (software: Cosmozone-1SA, Nikon, Japan). An estimate of the volume of ACTH cells was difficult because they were morphologically irregular in intact animals. The sections were magnified by 1192.1 -fold on a color display, and the cell outlines were traced on a magnetic tablet, by which the areas of the individual cells were put in a computer (PC-9801RX, NEC, Japan). We provided five animals for each experimental group, and estimated cell areas at random using sections through the central portion of the lateral lobes. Only cells containing the nucleus in the section were used for this measurement. The number of cells measured was 500 in each pituitary. The average cell areas were calculated, and the figures were statistically analyzed with Duncan's multiple range test. Statistical significance was accepted at $P<0.05$.

\section{RESULTS}

\section{Immunostaining with BuGR-2}

The brown color of DAB-reaction product for the glucocorticoid receptor and the blue reaction with cobalt for the pituitary hormones made it possible to visualize co-expression in the same cell of the glucocorticoid receptor and peptides in single sections. In the anterior pituitary of male rats, the majority (about $70 \%$ ) of ACTH cells and a minority of somatotrophs were immunoreactive for BuGR-2 (Fig. 1), but others appeared to be negative. In immunoreactive cells, the immunoreaction was confined to within the nuclei (Fig. 1).

BuGR-2-positive ACTH cells were predominantly small cells of stellate shape with several short and long processes and partly large polyhedral cells without prominent processes (Fig. 1). The small stellate ACTH cells occasionally embraced immunonegative cells with their processes. Some of the larger polyhedral ACTH cells showed vacuolar structures in the cell body. On days 3 and 14 after adrenalectomy, the immunoreaction to BuGR-2 totally disappeared in the nuclei of anterior pituitary cells. ACTH cells became hypertrophic and appeared polyhedral or spherical rather than stellate in shape (Fig. 1), the cytoplasmic processes no longer embracing other cells. Immunostainability for ACTH became fainter 3 days after adrenalectomy, but recovered to the same level as the intact animals on day 14 (Fig. 1). The cell bodies, however, revealed numerous fine vacuolar structures (Fig. 1). The average cell areas of corticotrophs were
$122.6 \pm 4.0 \mu \mathrm{m}^{2}$ and $144.7 \pm 3.8 \mu \mathrm{m}^{2}$ for the intact control and the sham-adrenalectomized animals, respectively. They were $172.4 \pm 2.9 \mu \mathrm{m}^{2}$ and $181.4 \pm 3.8 \mu \mathrm{m}^{2}$ 3 and 14 days after adrenalectomy (Fig. 2). The average cell areas of somatotrophs were $100.6 \pm 1.8 \mu \mathrm{m}^{2}$ and $99.3 \pm 1.7 \mu \mathrm{m}^{2}$ for the intact control and the sham-adrenalectomized animals, respectively. After adrenalectomy, the areas were significantly reduced to $87.6 \pm 1.4 \mu \mathrm{m}^{2}$ and $89.4 \pm 1.5 \mu \mathrm{m}^{2}$ at 3 and 14 days postsurgery (Fig. 2). Other anterior pituitary cells did not show distinct alterations in morphology.

After corticosterone replacement in adrenalectomized animals, we found only a slight recovery of stainability for BuGR-2 in the nuclei of ACTH cells.

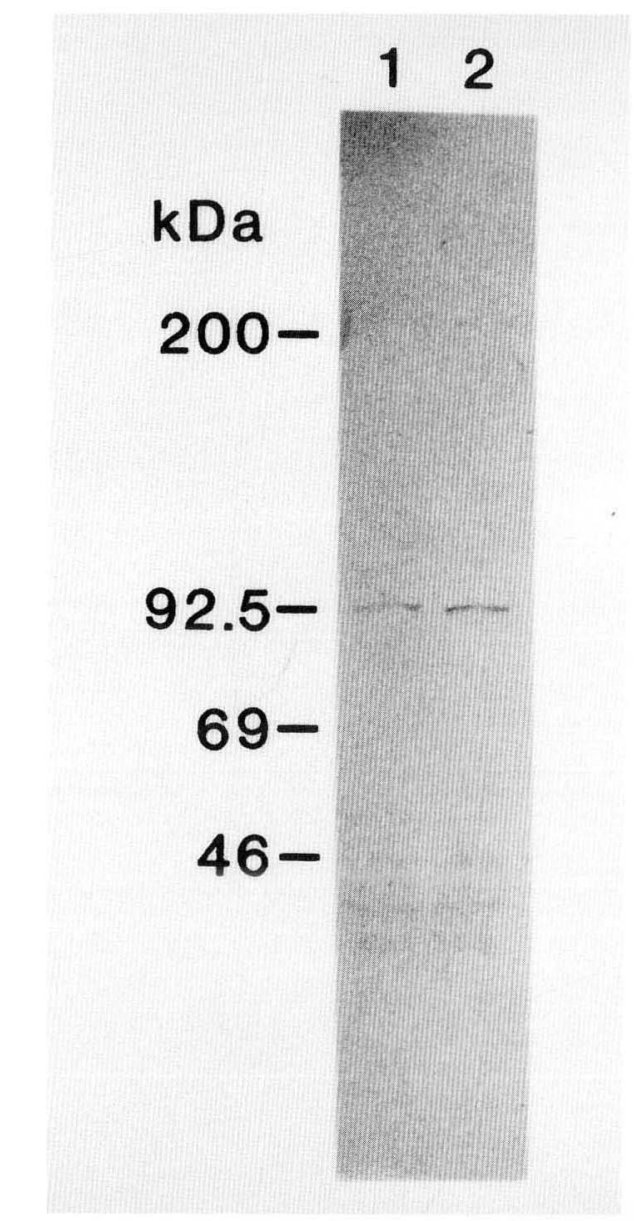

Fig. 3. Western blot of a glucocorticoid receptor. Liver cytosol $(40 \mu \mathrm{g})$ from an intact rat (lane 1) or adrenalectomized rat (lane 2) is loaded on SDS-PAGE as described in the text. After SDS-PAGE followed by transferring to Immobilon (Millipore), the glucocorticoid receptor was immunodetected with the $B_{1}$-antiserum as a probe. Sharp lines are found at the band of $92.5 \mathrm{kDa}$. 


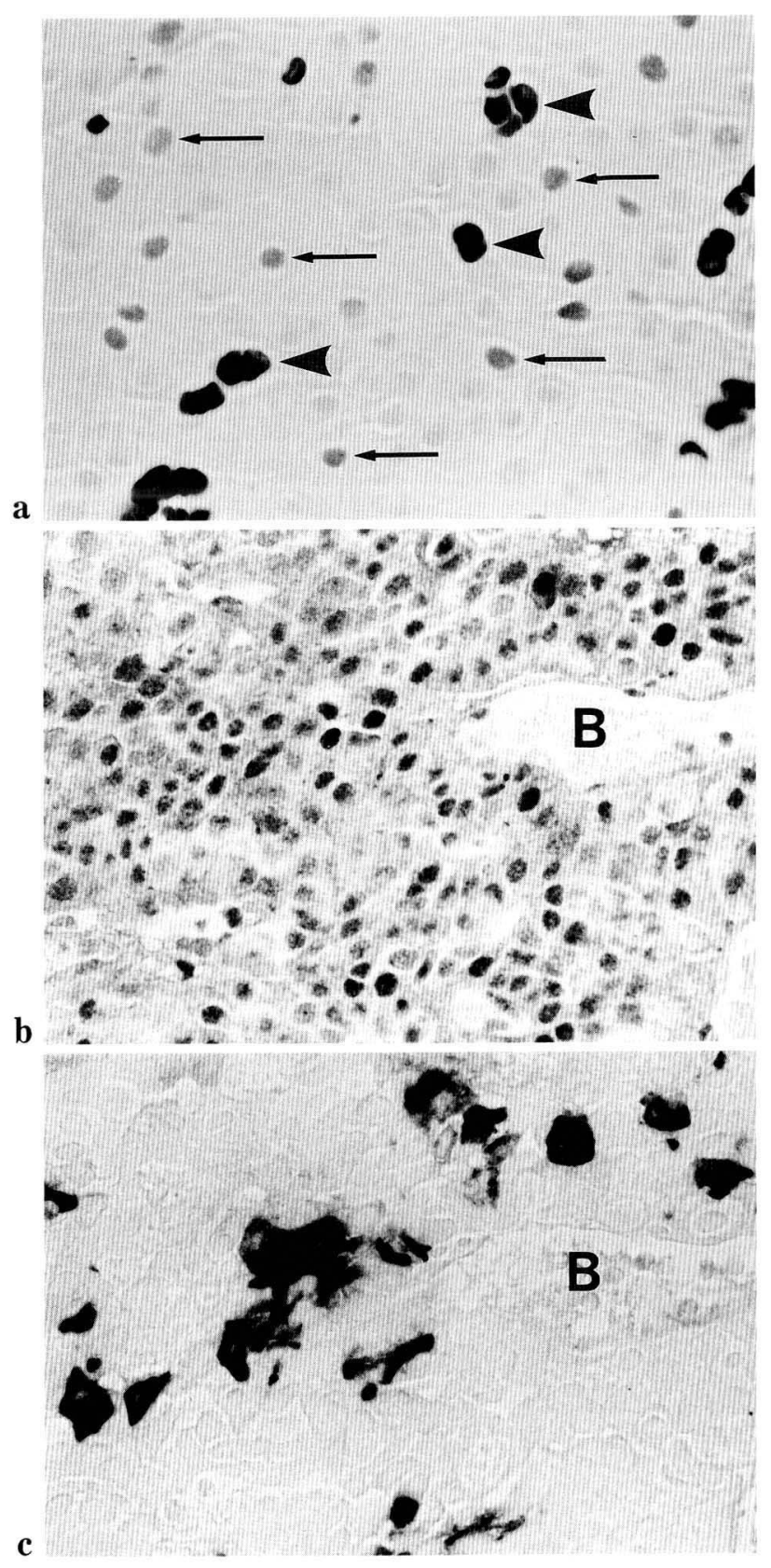

Fig. 4. Anterior pituitary of a normal rat. a. From a vibratome section immunostained with BuGR-2. b and c. Two adjacent serial paraffin sections, immunostained with the $\mathrm{B}_{1}$-antiserum (b) and with anti-ACTH serum (c). In $\mathbf{a}$, the glucocorticoid receptor immunoreaction is localized in the nuclei of many cells (arrows). Erythrocytes are shown with arrowheads. In $\mathbf{b}$, almost all cell nuclei are immunoreactive to the $\mathrm{B}_{1}$-antiserum; immunoreactive ACTH cells appearing in the adjacent section (c) are outnumbered by the $\mathrm{B}_{1}$-positive cells. $B$ blood vessel. a-c: $\times 500$
Immunoreaction to BuGR-2 was no longer evident after administrating corticosterone to the intact animals for seven days. The major ACTH cells were the polyhedral ones, whereas the stellate ones were rather minor in population. However, no morphological difference could be recognized in somatotrophs between the control and the corticosteroneadministered rats. The BuGR-2 reaction was not evident in the nucleus.

\section{Specificity tests of $\mathbf{B}_{1}$-antiserum}

$\mathrm{B}_{1}$-antiserum immunoadsorbed $\left[{ }^{3} \mathrm{H}\right]$-triamcinolone acetonide $\left(\left[{ }^{3} \mathrm{H}\right]\right.$-TA)-receptor complex with protein A sepharose. On the other hand, preimmune serum did not immunoadsorb the complex. The specific binding of $\left[{ }^{3} \mathrm{H}\right]$-TA to glucocorticoid receptor was $15000 \mathrm{cpm} / 150 \mu 1$ cytosol from the adrenalectomized rat. Thus at $4 \mu \mathrm{l}$ of the $\mathrm{B}_{1}$-antiserum, $73 \%$ of the receptor was adsorbed into protein $\mathrm{A}$ sepharose.

The monospecificity of $\mathrm{B}_{1}$-antiserum was confirmed by the Western blot analysis; the glucocorticoid receptor $(93 \mathrm{kDa}$ ) was detected as a single band. Pretreatment of the antiserum with antigenic peptide diminished the $93 \mathrm{kDa}$ receptor band (data not shown), and an intensified band was visible in the cytosol of the adrenalectomized rat (Fig. 3, lane 2).

\section{Immunostaining with $\mathrm{B}_{1}$-antiserum}

The immunoreaction for the $\mathrm{B}_{1}$-antiserum was confined to cellular nuclei, and found in almost all anterior pituitary cells (Fig. 4). However, a few cells also displayed the immunoreaction in the cytoplasm. In adjacent serial sections stained alternately with the $\mathrm{B}_{1}$-antiserum and with anti-ACTH serum, the number of $B_{1}$-positive cells exceeded that of ACTHpositive cells. Immunonegative cells, though few, were scattered throughout the tissue; their exact type could not be defined. Fourteen days after adrenalectomy, the immunoreaction became faint, but did not completely disappear as the BuGR reaction did. The nuclear and cytoplasmic staining became weaker and finally indistinct with the $B_{1}$ antiserum pre-absorbing with 1 or $10 \mu \mathrm{g} / \mathrm{ml}$ of the corresponding antigen.

\section{DISCUSSION}

The present study is the first to show that, in the rat anterior pituitary, ACTH cells and somatotrophs are immunoreactive for the glucocorticoid receptor and 
that morphological alterations occur in these cells following adrenalectomy and corticosteroneadministration. These findings suggest that the cells are the targets of corticosteroids.

As is well known, glucocorticoid secretion from the adrenal gland is under the regulation of $\mathrm{CRF}$ containing neurons and ACTH cells. ACTH released from ACTH cells in the adenohypophysis stimulates the secretion of glucocorticoids, and these in turn exert negative feedback effects on both the hypothalamus (ENDROCZI et al., 1961; YETES and URQUHART, 1962) and adenohypophysis (RUSSELL et al., 1969; MULDER and SMELIK, 1977). These feedback effects are thought to be mediated by the glucocorticoid receptor (GUSTAFSSON et al., 1983).

In the hypothalamus, it has been shown that CRFcontaining neurons are the sites of this feedback action, as the presence of glucocorticoid receptor in these neurons has been demonstrated (CINTRA et al., 1987; UHT et al., 1988). However, evidence is lacking in the adenohypophysis to accurately determine the feedback sites of glucocorticoids. Autoradiographic studies have demonstrated that some anterior pituitary cells incorporate radiolabeled glucocorticoids in their nuclei (REEs et al., 1975). Recent immunohistochemical studies (ANTAKLY and EISEN, 1984) have reported that the glucocorticoid receptor might occur in essentially all anterior pituitary cell nuclei and in some cell bodies. These authors used a polyclonal antibody for the glucocorticoid receptor obtained from liver cells (EISEN, 1980; EISEN et al., 1981), and emphasized that immunoreactive cells exceeded in number the corticotrophs, as identified by immunocytochemistry of ACTH. The same was obtained in our study using the $\mathrm{B}_{1}$-antiserum. The immunoreaction for the $B_{1}$-antiserum was localized in the nuclei of almost all anterior pituitary cells, but in the cytoplasm of only a few cells. The immunoreaction became faint after adrenalectomy but did not completely disappear as found in BuGR-2 staining. In the staining with the $\mathrm{B}_{1}$-antiserum pre-absorbed with the antigen, the nuclear and cytoplasmic immunoreactions became weaker and finally indistinct. These findings suggest that the $\mathrm{B}_{1}$-antiserum may crossreact with certain peptides, although the serum is immunologically monospecific against the amino acid sequence $407-423$ of rat glucocorticoid receptor protein.

In contrast with the findings obtained by using the $\mathrm{B}_{1}$-antiserum, the staining with BuGR-2 allowed us to demonstrate a glucocorticoid receptor in the nuclei of $\mathrm{ACTH}$ and GH cells. It seems, thus, that the localizations of the monoclonal and polyclonal antibodies are not identical, although they are exclusively confined in cell nuclei. A polyclonal antibody for corticosteroid-binding globulin prepared by PERROTApplanat et al. (1984) demonstrated the immunoreactivity in the cell bodies of corticotrophs. Most recently, ANTAKLy and his coworkers (1990) raised an antiserum to a synthetic peptide of the $\mathrm{N}$-terminal domain of human glucocorticoid receptor, and stained cell bodies of the anterior pituitary, but did not indicate the sort of cells.

Evidence has accumulated supporting the responsiveness of adenohypophysial cells to glucocorticoids. Glucocorticoids affect ACTH mRNA activity by modifying ACTH synthesis (NAKANISHI et al., 1977; Lim et al., 1982; KELLER-WoOD et al., 1984; WIDMAIER and Dallman, 1984; Abou-Samra et al., 1986; CedA and HofFMAN, 1986; LEVIN et al., 1988; DAYANITHI and ANTONI, 1989; FAMilari and Funder, 1989). Several works have also shown some effects of glucocorticoids on somatotrophs (MARTIAL et al., 1977; Evans et al., 1982; WEHRENBERG et al., 1983; SEIFERT et al., 1985; CEDA et al., 1987).

It has recently been shown by in situ hybridization that the GH mRNA level is influenced by glucocorticoids (MARTinoli and Pelletier, 1989). In accordance with these findings, the nuclear localization of the glucocorticoid receptor and the morphological alterations of cells presented here indicate that the sites of glucocorticoid action in the pituitary are ACTH cells and somatotrophs. Noteworthy, thereby, is the fact that the cell size changes that occurred in both cell types were reverse. The responsiveness of ACTH cells to adrenalectomy has been studied repeatedly by many investigators (CHILDS et al., 1983; WESTLUND et al., 1985).

This is the first report on the immunoreactivity for glucocorticoid receptor occurring in the nuclei of somatotrophs of intact animals and on the morphological alteration of somatotrophs in the adrenalectomized animals. Physiological studies have revealed the presence of stimulatory effects of corticosterone on somatotroph secretion (KOHLER et al., 1968, 1969; BANCROFT et al., 1969). Glucocorticoid treatment results in elevated plasma GH concentrations (WEHREnBERG et al., 1983; Mosier and JAN. SONS, 1985). CEDA et al. (1987) have shown that the effects of glucocorticoids on GH secretion are biphasic. During short incubations in a medium of the hypothalamus-hypophysis complex, dexamethasone placed in the medium inhibits GH-releasing hormone (GHRH) secretion and forskolin-elicited GH secretion, but during longer incubation, glucocorticoids enhance both basal and GHRH-stimulated GH release. Our morphometric data show that GH cells respond to adrenalectomy with a significant reduc- 
tion in size. If glucocorticoids elevate GH mRNA levels (MArtinoli and Pelletier, 1989) and enhance the responsiveness of GH cells to GHRH (VALE et al., 1983), this size decrease of the GH-cell seems to be consistent with the lowered synthesis of $\mathrm{GH}$ in the cells. It is of particular interest that hypothalamic GHRH-containing neurons also express a glucocorticoid receptor in rats (CINTRA et al., 1987).

From a morphological viewpoint, ACTH cells can be classified into two types, depending on the morphology of the secretory granules (MORIARTY and HALMI, 1972; BowiE et al., 1973; Yoshimura and Nogami, 1981; Kurosumi et al., 1984). The larger polyhedral type and small stellate type have been classified as types II and I, respectively, by KuRosumI and coworkers (1984). Our findings, however, show that both types are equally BuGR-2-positive. Our results moreover evidence that, in adrenalectomized animals, the small stellate cells change to the large polyhedral ones.

Acknowledgment. We are grateful to Dr. Ituro Inoue, Division of Enzyme Chemistry, Institute for Enzyme Research, University of Tokushima, Japan, for his kind help in the preparation of $\mathrm{B}_{1}$-antiserum and his advice in immunohistochemical staining.

\section{REFERENCES}

Abou-Samra, A.-B., K. J. Catt and G. Aguilera: Biphasic inhibition of adrenocorticotropin release by corticosterone in cultured anterior pituitary cells. Endocrinology 119: 972-977 (1986).

Antakly, T. and H. J. Eisen: Immunocytochemical localization of glucocorticoid receptor in target cells. Endocrinology 115: 1984-1989 (1984).

Antakly, T., A. Sasaki, A. S. Liotta, M. Palkovits and D. T. KRIEGER: Induced expression of the glucocorticoid receptor in the rat intermediate pituitary lobe. Science 229: 277-279 (1985).

Antakly, T., D. Raquidan, D. O'Donnell and L. Kat NICK: Regulation of glucocorticoid receptor expression: I. Use of a specific radioimmunoassay and antiserum to a synthetic peptide of the N-terminal domain. Endocrinology 126: 1821-1828 (1990).

Bancroft, F. C., L. Levine and A. H. Tashuian, Jr.: Control of growth hormone production by a clonal strain of rat pituitary cells. Stimulation by hydrocortisone. J. Cell Biol. 43: 432-441 (1969).

Bowie, E. P., G. Williams, M. Shitno and E. G. RenNELS: The corticotroph of the rat adenohypophysis: a comparative study. Amer. J. Anat. 138: 499-520 (1973).

Ceda, G. P. and A. R. Hoffman: Glucocorticoid modulation of corticotropin-releasing factor desensitization in cultured rat anterior pituitary cells. Endocrinology 118: 58-62 (1986).

Ceda, G. P., R. G. Davis and A. R. Hoffman: Glucocorticoid modulation of growth hormone secretion in vitro. Evidence for a biphasic effect on GH-releasing hormone mediated release. Acta Endocrinol. (Copenh.) 114: 465469 (1987).

Childs, G. V., D. G. Ellison, J. R. Lorenzen, T. J. Collins and N. B. Schwartz: Retarded development of castration cells after adrenalectomy or sham adrenalectomy. Endocrinology 113: 166-177 (1983).

Cintra, A., K. Fuxe, A. Härfstrand, L. F. Agnati, A.-C. Wikström, S. OKret, W. V ALE and J.-Å. Gus TAFSSON: Presence of glucocorticoid receptor immunoreactivity in corticotrophin releasing factor and in growth hormone releasing factor immunoreactive neurons of the di- and telencephalon. Neurosci. Lett. 77: 2530 (1987).

Daikoku, S., H. Kawano and K. Abe: Studies on the development of hypothalamic regulation of the hypophysial gonadotropic activity in rats. Arch. Anat. Microsc. Morphol. Exp. 69: 1-16 (1980).

Daikoku, S., H. Kawano, K. Abe and K. Yoshinaga: Topographical appearance of adenohypophysial cells with special reference to the development of the portal system. Arch. Histol. Jap. 44: 103-116 (1981).

Daikoku, S., M. Chikamori, T. Adachi, Y. OKamura, T. NishiYama and Y. Tsuruo: Ontogenesis of hypothalamic immunoreactive ACTH cells in vivo and in vitro: role of Rathke's pouch. Devel. Biol. 97: 81-88 (1983).

Dayanithi, G. and F. A. Antoni: Rapid as well as delayed inhibitory effects of glucocorticoid hormones on pituitary adrenocorticotropic hormone release are mediated by type II glucocorticoid receptors and require newly synthesized messenger ribonucleic acid as well as protein. Endocrinology 125: 308-313 (1989).

Eisen, H. J.: An antiserum to the rat liver glucocorticoid receptor. Proc. Nat. Acad. Sci. USA. 77: 3893-3897 (1980).

Eisen, H. J., R. E. Schleenbaker and S. S. Simons, Jr.: Affinity labeling of the rat liver glucocorticoid receptor with dexamethasone 21-mesylate. J. Biol. Chem. 256: 12920-12925 (1981).

Eisen, L. P., M. E. Reichman, E. B. Thompson, B. Gametchu, R. W. Harrison and H. J. Eisen: Monoclonal antibody to the rat glucocorticoid receptor. J. Biol. Chem. 260: 11805-11810 (1985).

ENDroczI, E., K. LisșâK and M. Tekeres: Hormonal "feed-back" regulation of pituitary-adrenocortical activity. Acta Physiol. Sci. Hung. 18: 291-299 (1961).

Evans, R. M., N. C. Birnberg and M. G. Rosenfeld: Glucocorticoid and thyroid hormones transcriptionally regulate growth hormone gene expression. Proc. Nat. Acad. Sci. USA. 79: 7659-7663 (1982).

FAmilari, M. and J. W. Funder: Isolated pituitary cells: glucocorticoids do not rapidly suppress ACTH secretion in response to CRF. Amer. J. Physiol. 256: E145-151 (1989). 
Fuxe, K., A.-C. Wikström, S. Okret, L. F. Agnati, A. Härfstrand, Z.-Y. Yu, L. Granholm, M. Zoli, W. VAlE and J.-A. Gustafsson: Mapping of glucocorticoid receptor immunoreactive neurons in the rat teland diencephalon using a monoclonal antibody against rat liver glucocorticoid receptor. Endocrinology 117: 1803-1812 (1985).

Gametchu, B. and R. W. HaRRison: Characterization of a monoclonal antibody to the rat liver glucocorticoid receptor. Endocrinology 114: 274-279 (1984).

Gustafsson, J.-A., S. OKret, A.-C. Wikström, B. An dersson, M. Radojcic, O. Wrange, W. SaChs, A. J. Doupe, P. H. Patterson, B. Cordell and K. Fuxe: On the use of poly- and monoclonal antibodies in studies on the structure and function of the glucocorticoid receptor. In: (ed. by) H. ERIKSSON and J.-A. GUSTAFSSON: Steroid hormone receptors: Structure and function. Elsevier Science Publishers, Amsterdam, 1983 (p. 355-388).

Gustafsson, J.-Å., J. Carlstedt-Duke, L. Poellinger, S. OKRET, A.-C. WiKströM, M. BrönNeGÅrd, M. GillNer, Y. Dong, K. Fuxe, A. Cintra, A. Härfstrand and L. Agnati: Biochemistry, molecular biology, and physiology of the glucocorticoid receptor. Endocrinol. Rev. 8: 185-234 (1987).

Hisano, S., T. Adachi and S. Daikoku: Immunolabeling of adenohypophysial cells with protein A-colloidal gold-antibody complex for electron microscopy: use of the freeze-substitution technique in tissue preparation. J. Histochem. Cytochem. 32: 705-711 (1984).

Hisano, S., Y. Kagotani, Y. Tsuruo, S. Daikoku, K. ChiHaRA and M. H. Whitnall: Localization of glucocorticoid receptor in neuropeptide Y-containing neurons in the arcuate nucleus of the rat hypothalamus. Neurosci. Lett. 95: 13-18 (1988).

Hsu, S.-M. and E. Soban: Color modification of diaminobenzidine (DAB) precipitation by metalic ions and its application for double immunohistochemistry. J. Histochem. Cytochem. 30: 1079-1082 (1982).

Keller-Wood, M., J. Shinsako and M. F. Dallman: Interaction between stimulus intensity and corticosteroid feedback in control of ACTH. Amer. J. Physiol. 247: E489-494 (1984).

Kohler, P. O., W. E. Bridson and P. L. RAYFord: Cortisol stimulation of growth hormone production by monkey adenohypophysis in tissue culture. Biochem. Biophys. Res. Commun. 33: 834-840 (1968).

Kohler, P. O., L. A. Frohman, W. E. Bridson, T. Vanha-Perttula and J. M. Hammond: Cortisol induction of growth hormone synthesis in a clonal line of rat pituitary tumor cells in culture. Science 166: 633634 (1969).

Kurosumi, K., Y. Taniguchi and K. Inoue: Electron microscopic immunocytochemistry by the protein Agold method of two types of rat anterior pituitary ACTH cells. Arch. Histol. Jap. 47: 279-291 (1984).

Levin, N., J. Shinsako and M. F. Dallman : Corticosterone acts on the brain to inhibit adrenalectomy-induced adrenocorticotropin secretion. Endocrinology 122: 694-
701 (1988).

Lim, A. T., B. A. K. Khalid, J. Clements and J. W. FUNDER: Glucocorticoid and mineralocorticoid effects on adrenocorticotropin and $\beta$-endorphin in the adrenalectomized rat. J. Clin. Invest. 69: 1191-1198 (1982).

Liposits, Zs., R. M. Uht, R. W. Harrison, F. P. GibBs, W. K. Paull and M. C. Bohn: Ultrastructural localization of glucocorticoid receptor $(\mathrm{GR})$ in hypothalamic paraventricular neurons synthesizing corticotropin releasing factor (CRF). Histochemistry 87: 407-412 (1987).

Martial, J. A., P. H. Seeburg, D. Guenzi, H. M. Goodman and J. D. BAXTER: Regulation of growth hormone gene expression: synergistic effects of thyroid and glucocorticoid hormones. Proc. Nat. Acad. Sci. USA. 74: 4293-4295 (1977).

Martinoli, M. G. and G. Pelletier: Thyroid and glucocorticoid hormone regulation of rat pituitary growth hormone messenger ribonucleic acid as revealed by in situ hybridization. Endocrinology 125: 1246-1252 (1989).

Miesfeld, R., S. Rusconi, P. J. Godowski, B. A. Maler, S. Okret, A.-C. Wikström, J.-Å. Gustafsson and K. R. Yамамото: Genetic complementation of a glucocorticoid receptor deficiency by expression of cloned receptor cDNA. Cell 46: 389-399 (1986).

Moriarty, G. C. and N. S. Halmi: Electron microscopic study of the adrenocorticotropin-producing cell with the use of unlabeled antibody and the soluble peroxidase-antiperoxidase complex. J. Histochem. Cytochem. 20: 590-603 (1972).

Mosier, H. D., Jr. and R. A. Jansons: Increase in pulsatile secretion of growth hormone during failure of catch-up growth following glucocorticoid-induced growth inhibition. Proc. Soc. Exp. Biol. Med. 178: $457-$ 461 (1985).

Mulder, G. H. and P. G. Smelik: A superfusion system technique for the study of the sites of action of glucocorticoids in the rat hypothalamus-pituitaryadrenal system in vitro. I. Pituitary cell superfusion. Endocrinology 100: 1143-1152 (1977).

Nakanishi, S., T. Kita, S. TaiI, H. Imura and S. Numa: Glucocorticoid effect on the level of corticotropin messenger RNA activity in rat pituitary. Proc. Nat. Acad. Sci. USA. 74: 3283-3286 (1977).

O'Callaghan, J. P., R. E. BRinton and B. S. McEwen: Glucocorticoids regulate the concentration of glial fibrillary acidic protein throughout the brain. Brain Res. 494: 159-161 (1989).

Papamichail, M., G. Tsokos, N. Tsawdaroglou and C. E. SEKERIS: Immunocytochemical demonstration of glucocorticoid receptors in different cell types and their translocation from the cytoplasm to the cell nucleus in the presence of dexamethasone. Exp. Cell Res. 125: 490493 (1980).

Perrot-Applanat, M., O. Racadot and E. Milgrom: Specific localization of plasma corticosteroid-binding globulin immunoreactivity in pituitary corticotrophs. Endocrinology 115: 559-569 (1984). 
PiCARD, D. and K. R. Yamamoto: Two signals mediate hormone-dependent nuclear localization of the glucocorticoid receptor. EMBO J. 6: 3333-3340 (1987).

Rees, H. D., W. E. STumPF and M. SAR: Autoradiographic studies with ${ }^{3} \mathrm{H}$-dexamethasone in the rat brain and pituitary. In: (ed. by) W. E. STUMPF and L. D. GRANT: Anatomical neuroendocrinology. Karger, Basel, 1975 (p. 262-269).

Russell, S. M., A. P. S. Dhariwal, S. M. McCann and F. E. YETES: Inhibition by dexamethasone of the in vivo pituitary response to corticotropin-releasing factor (CRF). Endocrinology 85: 512-521 (1969).

Sapolsky, R. M., L. C. Krey and B. S. MCEwen: Prolonged glucocorticoid exposure reduces hippocampal neuron number: implications for aging. J. Neurosci. 5: 1222-1227 (1985).

Seifert, H., M. Perrin, J. Rivier and W. Vale: Growth hormone-releasing factor binding sites in rat anterior pituitary membrane homogenates: modulation by glucocorticoids. Endocrinology 117: 424-426 (1985).

Uht, R. M., J. F. MCKelvy, R. M. HarRison and M. C. Boнn: Demonstration of glucocorticoid receptor-like immunoreactivity in glucocorticoid-sensitive vasopressin and corticotropin-releasing factor neurons in the hypothalamic paraventricular nucleus. J. Neurosci. Res. 19: 405-411 (1988).

Vale, W., J. Vaughan, G. Yamamoto, J. Spiess and J. RIVIER: Effects of synthetic human pancreatic (tumor) $\mathrm{GH}$ releasing factor and somatostatin, triiodothyronine and dexamethasone on GH secretion in vitro. Endocrinology 112: 1553-1555 (1983).

Wakabayashi, $K$. and S. Tanaka: Assessment of specificity of antisera for immunohistochemistry. Acta Histochem. Cytochem. 21: 221-229 (1988).

Wehrenberg, W. B., A. Baird and N. Ling: Potent interaction between glucocorticoids and growth hormone-releasing factor in vivo. Science 221: 556-558 (1983).
Westlund, K. N., G. Aguilera and G. V. Childs: Quantification of morphological changes in pituitary corticotropes produced by in vivo corticotropinreleasing factor stimulation and adrenalectomy. Endocrinology 116: 439-445 (1985).

Widmaier, E. P. and M. F. Dallman: The effects of corticotropin-releasing factor on adrenocorticotropin secretion from perifused pituitaries in vitro: Rapid inhibition by glucocorticoids. Endocrinology 115: 23682374 (1984).

YeTES, F. E. and J. URQUhART: Control of plasma concentrations of adrenocortical hormones. Physiol. Rev. 42: 359-443 (1962).

Yoshimura, F. and H. Nogami: Fine structural criteria for identifying rat corticotrophs. Cell Tiss. Res. 219: 221-228 (1981).
Prof. Shigeo DAIKOKU Department of Anatomy School of Medicine The University of Tokushima 3-18-15 Kuramoto Tokushima, 770 Japan

大黒成夫 770 徳島市蔵本町 3 丁目 18-15 徳島大学医学部 解剖学第二講座 